Gelanggang Olahraga: Jurnal Pendidikan Jasmani dan Olahraga

Volume 1, Nomor 2, Januari-Juni 2018

e-ISSN : 2597-6567

p-ISSN : 2614-607X

DOI : https://doi.org/10.31539/jpjo.v1i2.159

\title{
PELAKSANAAN MODIFIKASI PERMAINAN KECIL DALAM PEMBELAJARAN PENJASORKES
}

\author{
Ever Sovensi \\ STKIP-PGRI Lubuklinggau \\ Ever_sovensi@yahoo.co.id
}

\begin{abstract}
ABSTRAK
Tujuan penelitian ini adalah untuk mengetahui pelaksanaan modifikasi pembelajaran Penjasorkes. Penelitian ini menggunakan metodedeskriptif. Populasi penelitian adalah 121 orang. Penarikan sampel dilakukan dengan teknik purposive random sampling, didapat sampel berjumlah 58 orang. Instrumen yang dipakai untuk mengumpulkan data adalah angket dengan menggunakan skala Guttman. Data dianalisis dengan menggunakan rumus distribusi frekuensi dalam bentuk persentase. Hasil penelitian sebagai berikut: tingkat capaian motivasi siswa yang ada di Sekolah Dasar Negeri 27 berada pada klasifikasi sangat baik, yaitu dengan tingkat capaian jawaban responden mencapai 85\%. Tingkat capaian metode pengajaran pada pelaksanaan modifikasi permainan kecil dalam pembelajaran Penjasorkes di Sekolah Dasar Negeri 27 Pangianberada pada klasifikasi sangat baik, yaitu dengan tingkat capaian sebesar 85,86\%. Tingkat capaian sarana dan prasarana terhadap pelaksanaan modifikasi permainan kecil dalam pembelajaran Penjasorkes di Sekolah Dasar Negeri 27 Pangian berada pada klasifikasi baik, yaitu dengan tingkat capaian jawaban responden mencapai $74,65 \%$.
\end{abstract}

Kata Kunci:Modifikasi,Penjasorkes

\section{ABSTRACT}

The purpose of this study is to know the description of the implementation of modification learning penjasorkes. This research uses a descriptive method. The study population was 121 people. Sampling was done by Purposive random sampling, got sample amounted to 58 people. The instrument used to collect data is Questionnaire or questionnaire using Guttman scale. Data were analyzed by using frequency distribution formula in percentage form. The results of the study are as follows: the level of achievement of student's motivation in State Elementary School 27 is in very good classification, that is with the achievement of respondent answer reach 85\%. The level of teaching method achievement in the implementation of small game modification in the learning of penjasorkes at the Pangian State Elementary School is in a very good classification, with an achievement rate of $85.86 \%$. The level of achievement of the facilities and infrastructure for the implementation of small game modification in the learning of penjasorkes in Public Elementary School 27 Pangian is in good classification, that is with the level of respondents achievement reaches $74.65 \%$.

Keywords: Modification, Penjasorkes 


\section{PENDAHULUAN}

Pendidikan jasmani adalah suatu bagian dari pendidikan keseluruhan yang mengutamakan aktifitas dan pembinaan hidup sehat untuk pertumbuhan dan perkembangan jasmani, mental, sosial dan emosional yang serasi, selaras dan seimbang agar:

1) tercapai pertumbuhan dan perkembangan jasmani khususnya tinggi, berat badan secara harmonis; 2) mengembangkan kesehatan dan kesegaran jasmani keterampilan gerak cabang olahraga; 3) mengerti arti pertumbuhan jasmani dan mental; 4) mengerti peraturan olahraga; 5) menyenangi aktivitas jasmani yang dapat dipakai untuk pengisian waktu luang serta kebiasaan hidup sehat, mengerti dan dapat menetapkan prinsip-prinsip pengutamaan pencegahan penyakit dalam kaitannya dengan kesehatan (Depdikbud, 1993)

Berdasarkan kutipan diatas, mata pelajaran Penjasorkes adalah salah satu mata pelajaran yang dapat meningktkan kualitas sumber daya manusia Indonesia.Dalam pendidikan jasmani ada empat aspek yang perlu dikembangkan seperti aspek motorik, efektif, kognitif dan sosial. Berdasarkan keempat komponen tersebut tidak dapat dipisahkan satu dengan yang lainnya artinya saling berkaitan.

Keberhasilan pelajaran Penjasorkes akan tergambar pada kemampuan dan keterampilan guru dalam mangaplikasikan semua bentuk atau materi yang sudah dirancang sebelumnya dengan sistematis agar siswa merasa tertarik dan senang melakukan olahraga. Untuk itu, yang perlu dilakukan seorang guru terhadap anak didiknya adalah bagaimana menciptakan suasana belajar yang bergairah, menarik sehingga siswa senang dan tidak jenuh dalam mengikuti pelajaran Penjasorkes.

Untuk dapat menghasilkan hal tersebut maka perlu adanya metode pembelajaran yang tepat. Salah satu metode pembelajaran yang perlu dan dibutuhkan dalam mata pelajaran Penjasorkes adalah dengan membuat modifikasi. Dengan membuat modifikasi pembelajaran yang tepat yang sifatnya spesifikasi dan menarik tentunya akan dapat menarik minat siswa untuk mengikuti pembelajaran Penjasorkes.

Namun pada kenyataannya di lapangan, sesuai hasil observasi yang penulis lakukan di Sekolah Dasar Negeri 27 Pangian dalam pelaksanaan pembelajaran Penjasorkes masih ada guru Penjasorkes kurang memperhatikan kemampuan siswa, materi, sarana dan prasarana, dan motivasi siswa. Sebagai contoh dalam mengajarkan bola voli di sekolah menggunakan bola voli, ukuran lapangan, tinggi net dan peraturan untuk orang dewasa. Tentu semua ini akan mengakibatkan siswa kurang termotivasi dalam melakukan olahraga apalagi pada anak-anak Sekolah dasar yang masih dalam masa bermain. Dengan adanya modifikasi alat-alat dan peraturan kemungkinan siswa lebih termotivasi dalam proses belajar mengajar secara baik. Sebab setiap partisipasinya mendorong untuk bekerja sama dan merasa senang. 


\section{KAJIAN TEORI}

Charles Bucher (1972) mengemukakan pendidikan jasmani adalah bagian yang dari proses pendidikan yang menyeluruh. Bidang sasaran yang diusahakan adalah perkembangan jasmaniah, mental, emosional dan sosial bagi warga negara yang sehat melalui medium kegiatan jasmaniah.Berdasarkan kutipan diatas berarti kesegaran jasmani merupakancermin dari kemampuan fungsi sistem-sistem organ dalam tubuh yang dapat mewujudkan sesuatu peningkatan kualitas hidup dalam setiap aktifitas fisik.

Tujuan pendidikan jasmani dan kesehatan menurut Depdikbud jasmani dan kesehatan di Sekolah Dasar (1993) yakni membantu siswa untuk meningkatkan kesegaran jasmani dan kesehatan melalui pengenalan dan pemahaman sikap positif serta kemampuan gerak dasar berbagai aktifitas jasmani agar dapat;tercapainya pertumbuhan dan perkembangan jasmani, khususnya tinggi dan berat secara harmonis dan ideal.Terbentuknya sikap dan perilaku seperti disiplin, kejujuran, kerjasama, mengikuti peraturan dan ketentuan yang berlaku. Menyenangi aktifitas jasmani yang dapat dipakai dalam pengisian waktu luang serta kebiasaan hidup sehat.Mempunyai kemampuan untuk menjelaskan tentang manfaat pendidikan jasmani dan kesehatan serta mempunyai kemampuan penampilan, keterampilan gerak efektif dan efisien.Meningkatkan kesegaran jasmani dan kesehatan serta daya tahan tubuh terhadap penyakit".

Uraian di atas dapat disimpulkan bahwa dengan mempelajari pendidikan jasmani dan kesehatan di sekolah siswa dapat meningkatkan kesegaran jasmani dan dapat meningkatkan daya tahan tubuh dan penyakit serta mempunyai kemampuan keterampilan terhada gerak secara efektif dan efisien.

Aktivitas bermain menurut Matakupan dalam Gusril (2004) adalah suatu kegiatan yang dilakuakn dengan sungguh-sungguh karena disenangi. Sedangkan menurut Seefelt dan Barbour dalam Gusril (2004) aktivitas bermain merupakan“ suatu kegiatan yang spontan pada masa anak-anak yang menghubungkannya dengan kegiatan orang dewasa dan lingkungan termasuk dalam imajinasi, penampilan anak dengan menggunakan seluruh perasaan, tangan atau seluruh badan".Dari uraian di atas dapat disimpulkan bahwa bermain adalah suatu kegiatan yang melibatkan aktifitas fisik atau mental seorang anak (siswa) sehingga dapat mempengaruhi dalam bidang kehidupan.Terlihat dari kegiatan bermain dapat menyenangkan, menggembirakan, spontan, sukarela, cukup aktif dan mempunyai tujuan-tujuan tertentu.

Jadi, untuk mencapai tujuan Pendidikan Jasmani, Olahraga dan Kesehatan maka permainan merupakan salah satu bentuk alatnya, diantaranya permainan kecil. Karena Permainan kecil yang diberikan dalam pembelajaran bermanfaat bagi pembinaan keterampilan gerak maksudnya guru tidak mungkin akan memberikan pelajaran secara berkepanjangan melalui penjelasan dan penemuan saja.

\section{METODE PENELITIAN}

Penelitian ini tergolong pada penelitian deskriptif.Arikunto (1996) mendefinisikan bahwa"penelitian deskriptif" adalah penelitian yang tidak bermaksud untuk menguji hipotesis tertentu tetapi hanya menggambarkan apa adanya tentang suatu variabel gejala atau keadaan".Berdasarkan pendapat tersebut maka pada penelitian ini hanya mengungkapkan atau menggambarkan suatu 
gejala semata yaitu melihat bagaimana pelaksanaan modifikasi permainan kecil dalam proses belajar mengajar praktek pendidikan jasmani di Sekolah Dasar Negeri.

Penelitian ini diadakan di Sekolah Dasar Negeri 27 Pangian dan waktu pengambilan data dilakukan pada bulan November 2014. Populasi dalam penelitian ini adalah siswa Sekolah Dasar Negeri 27 Pangian yang berjumlah 87 orang. Pengambilan sampel dilakukan dengan teknik Purposive sampling yakni siswa kelas IV dan $\mathrm{V}$, peneliti mengambil populasi kelas IV dan $\mathrm{V}$ dengan pertimbangan bahwa kelas VI sudah ujian (tamat) dan kelas IV dan V memiliki kesempatan cukup lama untuk menerapkan keterampilan belajar sedangan anak kelas 1, 2 dan 3 belum mampu mengikuti test tersebut. Jadi jumlah sampel dalam penelitian ini berjumlah 58 orang.

Jenis data dalam penelitian ini adalah bersifat primer dan sekunder, yang dimaksud data primer didalam penelitian ini adalah data yang langsung diperoleh dari responden dengan cara menyebarkan angket atau kuesioner terbuka kepada kelas IV, V sedangkan data sekunder adalah data yang diambil secara tidak langsung dari sumbernya yaitu melalui dokumen-dokumen yang ada di sekolah. Sumber data primer diperoleh langsung dari jawaban sampel di Sekolah Dasar Negeri 27 Pangian sebagai responden yang diisi melalui penyebaran angket, sedangkan untuk data sekunder, diambil dari tata usaha serta kearsipan yang ada di sekolah.

Teknik dan alat pengumpulan data penelitian ini adalah mengunakan angket. Langkah-langkah yang dilakukan dalam pembuatan angket yaitu memasukan variable kepada indikator-indikator dan membuat kisi-kisi sesuai dengan data yang diperlukan dalam penelitian ini, maka teknik yang di gunakan adalah dengan pengisian angket ( kuesioner), wawancara, dan observasi langsung. Namun data yang diolah hanyalah data dari pengisian angket. Untuk lebih jelasnya gambaran angket dapat dilihat pada kisi-kisi angket yang akan dibuat. Angket tersebut merupakan angket tertutup ( angket berstruktur ) yaitu angket yang disajikan dalam bentuk sedemikian rupa sehingga responden diminta untuk memilih satu jawaban.Untuk lebih jelasnya gambaran angket dapat dilihat pada table kisi-kisi angket berikut ini :

Tabel 1

Kisi-kisi Angket

\begin{tabular}{|c|c|c|c|}
\hline Variabel & Indikator & Sub Indikator & Butir Soal \\
\hline Pelaksanaan & 1. Motivasi & a. $\quad$ Intrinsik & $1 \mathrm{~s} / \mathrm{d} 7$ \\
\hline Modifikasi & siswa & Ekstrinsik & $8 \mathrm{~s} / \mathrm{d} 10$ \\
\hline Permainan & 2. Metode & & \\
\hline Kecil dalam & Pengajaran & & $11 \mathrm{~s} / \mathrm{d} 20$ \\
\hline Proses & 3. Sarana dan & & $21 \mathrm{~s} / \mathrm{d} 30$ \\
\hline Pembelajaran & Prasarana & & \\
\hline Mengajar & & & \\
\hline Penjasorkes & & & \\
\hline
\end{tabular}


Tabel 2

Angket Penelitian Pelaksanaan Modifikasi Permainan Kecil Dalam Pembelajaran Penjasorkes

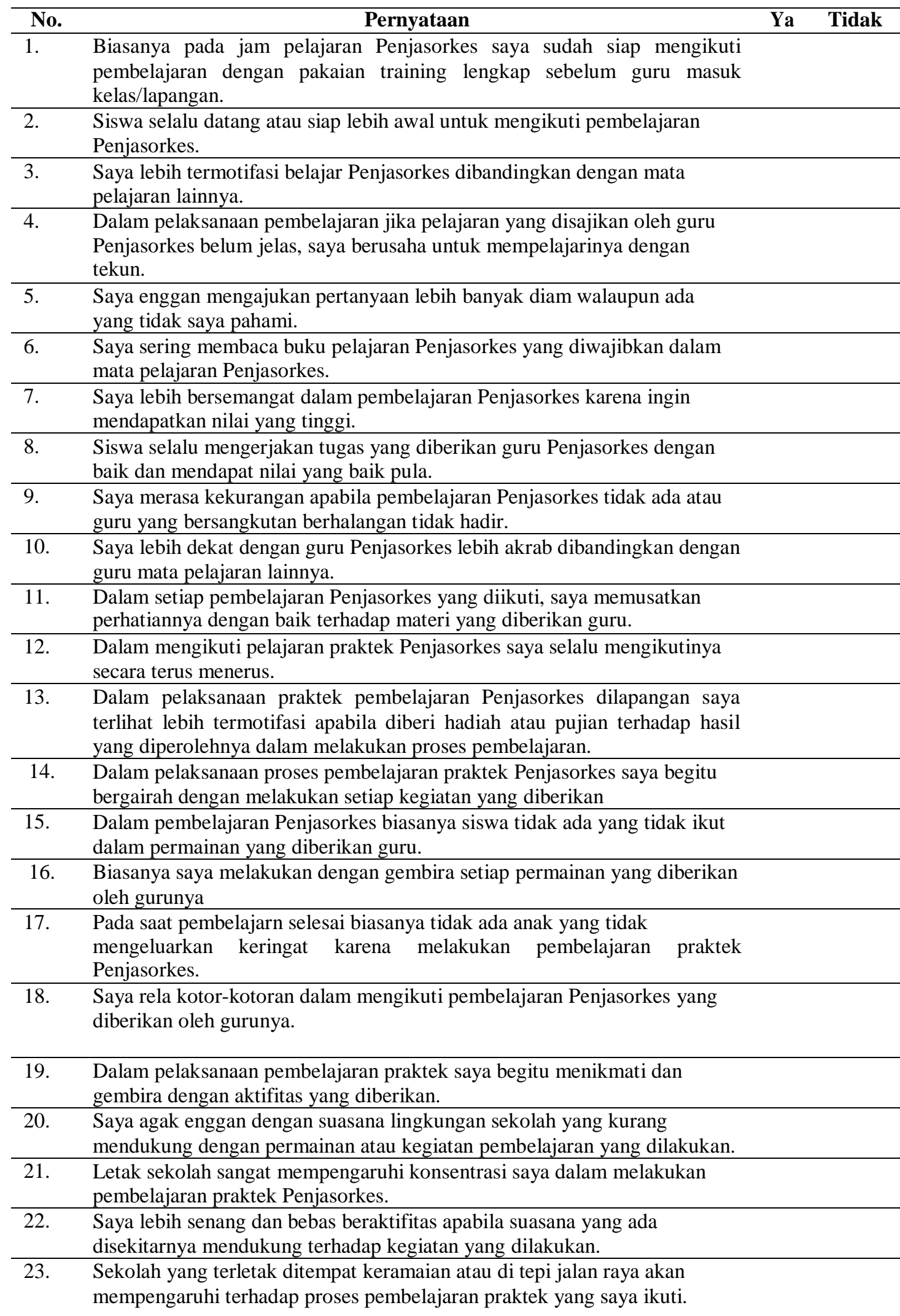




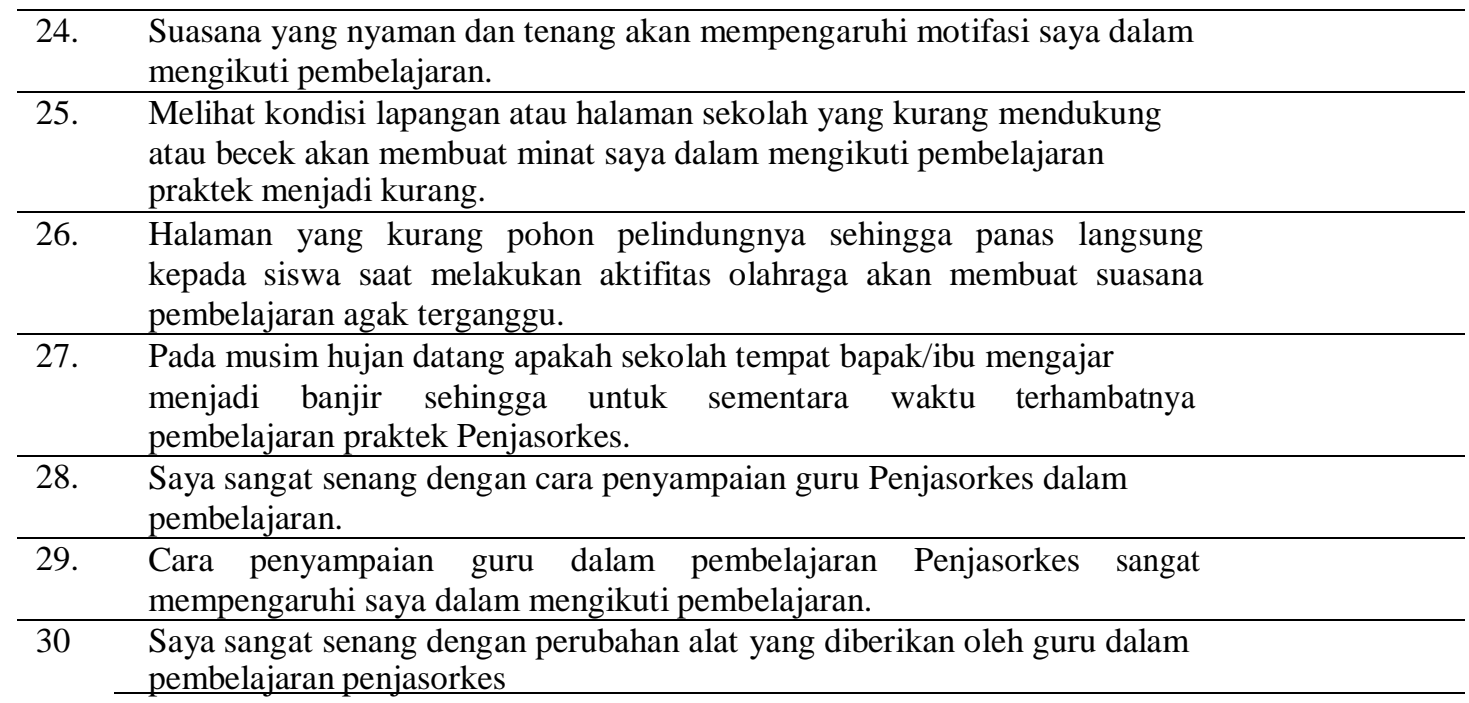

Pengumpulan data menggunakan kuesioner atau dengan cara penyebaran angket. Tentangpelaksanaan modifikasi permainan kecil dalam pembelajaran penjasorkes. Angket dimulai dengan membuat kisi-kisi, mulai dari variable, sup variabel dan butir soal yang berupa pernyataan. Jenis angket yang digunakan dalam angket tertutup, jawaban diminta untuk memilih jawaban yang telah tersedia.Skala pengukuran yang digunakan adalah skala Guttman, jawaban, "ya" dan "tidak " berdasarkan kutipan dari suwirman (2004) bahwa"Skala Guttman adalah skala yang digunakan untuk jawaban yang bersifat jelas atau tegas dan konsisten. Untuk jawaban "Ya" diberi skor 1, sedangkan jawaban "Tidak" mendapat skor 0.Teknik analisis data yang digunakan statistik deskriptif yang menggunakan tabulasi frekwensi.

Setelah angket disebarkan dan dikumpulkan, selanjutnya dilakukan pengolahan data berdasarkan angket yang telah dikumpulkan dan telah memenuhi syarat untuk dianalisis. Teknik analisis data yang digunakan statistik deskriptif yang menggunakan tabulasi frekwensi (Sudjana, 1990).Angket yang telah dikumpulkan kemudian dianalisis dengan langkah-langkah sebagai berikut :

1. Memeriksa semua angket yang telah diisi siswa

2. membuat tabel persiapan untuk tabulasi data

3. menghitung frekwensi dari alternatif jawaban yang diberikan

4. menghitung frekwensi jawaban dengan rumus :

$$
\mathbf{P}=\frac{F}{N} x 100 \%
$$

Keterangan :

$\mathrm{P}=$ Jumlah persentase

jawaban $\mathrm{F}=$ Frekwensi

$\mathrm{N}=$ Jumlah Responden 
Skor motivasi belajar siswa yang berupa data kuantitatif dikualifikasikan sebagai berikut :

\begin{tabular}{ll}
\hline $81 \%-100 \%$ & $=$ Sangat baik \\
\hline $61 \%-80 \%$ & $=$ Baik \\
\hline $41 \%-60 \%$ & $=$ Cukup \\
\hline $21 \%-40 \%$ & $=$ Kurang \\
\hline $0 \%-20 \%$ & $=$ Kurang sekali(Arikunto 1998) \\
\hline
\end{tabular}

\section{HASIL PENELITIAN}

\section{Motivasi Siswa}

Tingkat capaian motivasi siswa dalam pelaksanaan modifikasi permainan kecil dalam pembelajaran penjasorkes di Sekolah Dasar Negeri 27, penulis memberikan 10 butir pertanyaan terhadap 58 responden.Adapun hasil dari jawaban responden bisa dilihat pada tabel berikut :

Tabel 3

Deskripsi Motivasi

\begin{tabular}{ccccc}
\hline No & $\begin{array}{c}\text { Kategori } \\
\text { Jawaban }\end{array}$ & $\begin{array}{c}\text { Jumlah Jawaban } \\
\text { Responden }\end{array}$ & $\begin{array}{c}\text { Persentase } \\
(\boldsymbol{\%})\end{array}$ & $\begin{array}{c}\text { Tingkat } \\
\text { Capaian }\end{array}$ \\
\hline 1 & Ya & 493 & 85 & \\
\cline { 1 - 3 } 2 & Tidak & 87 & 15 & \\
\cline { 1 - 3 } & Jumlah & 580 & 100 & $85 \%$ \\
\hline
\end{tabular}

Pada tabel di atas dapat diketahui bahwa dari 58 responden dan dari 10 buah pertanyaan, yang memilih jawaban "Ya" sebanyak 493 responden atau $85 \%$. Dan yang menjawab "Tidak" adalah 87 responden atau $15 \%$.Secara keseluruhan tingkat capaian motivasi siswa untuk mengikuti pembelajaran penjasorkes yang ada di Sekolah Dasar Negeri 27 Pangianberada pada klasifikasi sangat baik. Gambaran lebih jelasnya deskripsi motivasi dapat dilihat pada grafik histogram berikut ini:

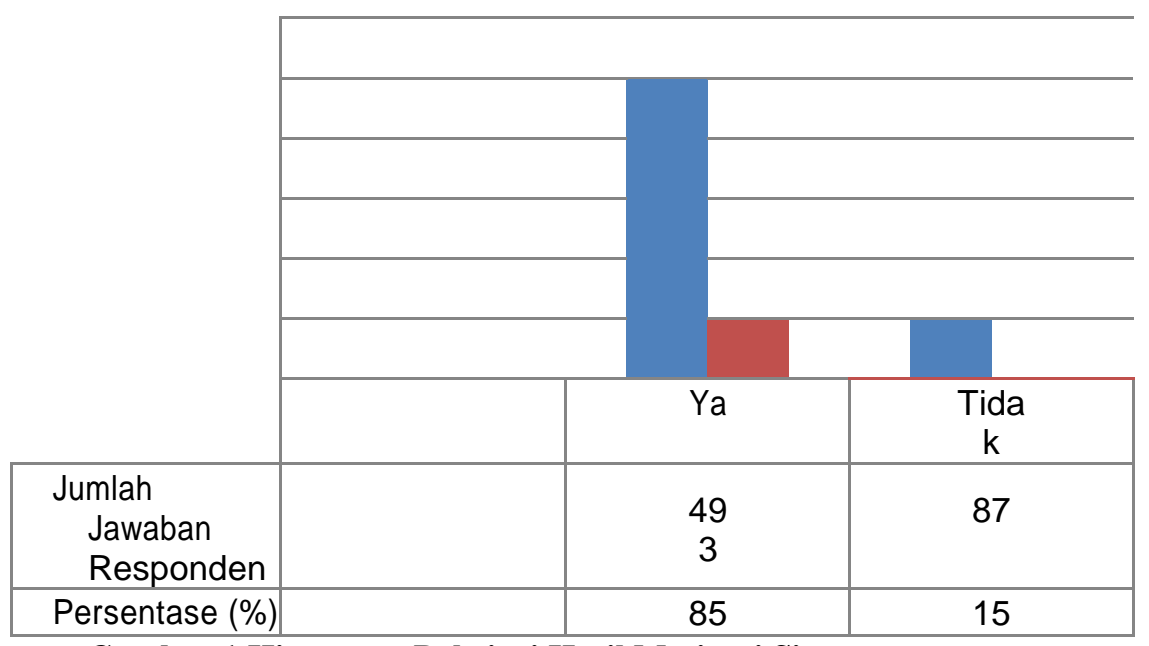

Gambar 1.Histogram Dskripsi Hasil Motivasi Siswa 


\section{Metode Pembelajaran}

Untuk melihat keadaan metode pengajaran terhadap pelaksanaan modifikasi permainan kecil dalam pembelajaran penjasorkes di Sekolah Dasar Negeri 27, penulis memberikan 10 butir pertanyaan terhadap 58 responden.Adapun hasil dari jawaban responden bisa dilihat pada tabel berikut :

Tabel 4

Deskripsi Metode Pengajaran

\begin{tabular}{ccccc}
\hline No & $\begin{array}{c}\text { Kategori } \\
\text { Jawaban }\end{array}$ & $\begin{array}{l}\text { JumlahJawaban } \\
\text { Responden }\end{array}$ & $\begin{array}{c}\text { Persentase } \\
(\boldsymbol{\%})\end{array}$ & $\begin{array}{c}\text { Tingkat } \\
\text { Capaian }\end{array}$ \\
\cline { 1 - 4 } 1 & Ya & 398 & 85.86 & \\
\cline { 1 - 4 } 2 & Tidak & 82 & 14,13 & \\
\cline { 1 - 3 } & Jumlah & 580 & 100 & $85,86 \%$ \\
\hline
\end{tabular}

Pada Tabel di atas dapat diketahui bahwa dari 58 responden dan dari 10 buah pernyataan, yang memilih jawaban "Ya" sebanyak 372 responden atau $85,86 \%$. Dan yang menjawab "Tidak" adalah 82 responden atau $14,13 \%$. Secara keseluruhan tingkat capaian Metode pembelajaran bagi siswa dalam pelaksanaan modifikasi permainan kecil dalam pembelajaran penjasorkes yang ada di Sekolah Dasar Negeri 27 Pangianberada pada klasifikasi Sangat baik. Untuk lebih jelasnya variabel Metode pembelajaran dapat dilihat pada gambar histogram di bawah ini:

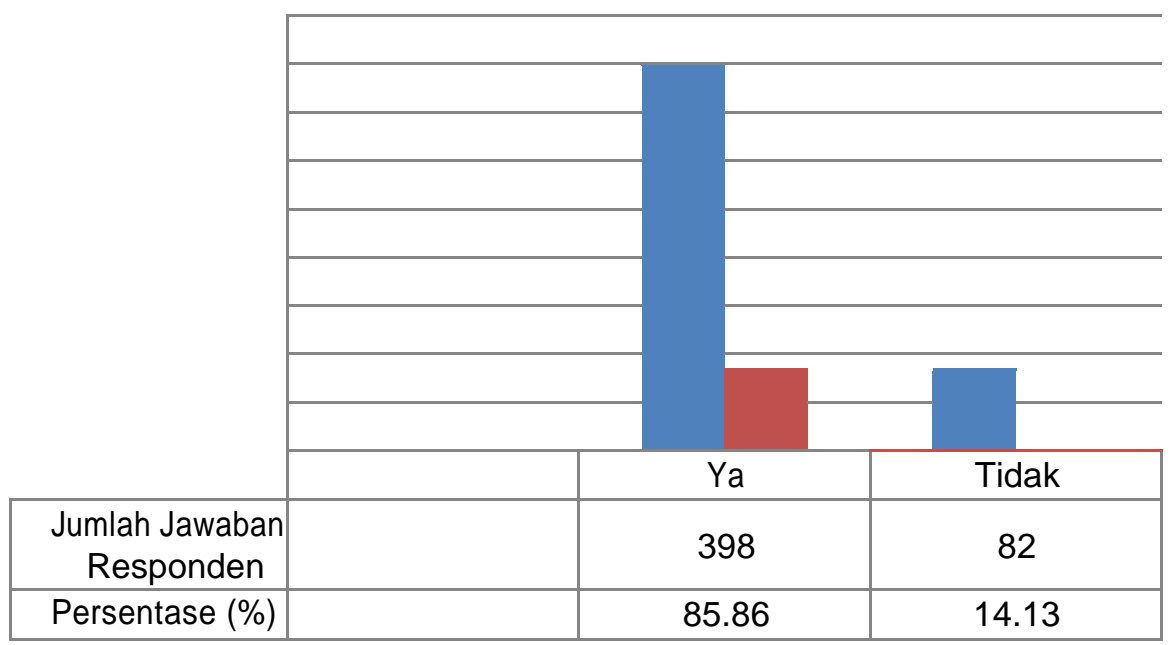

Gambar 2.Histogram Deskripsi Hasil MetodePembelajaran

\section{Sarana dan Prasarana}

Untuk melihat sarana dan prasarana dalampelaksanaan modifikasi permainan kecil dalam pembelajaran penjasorkes di Sekolah Dasar Negeri 27, penulis memberikan 10 butir pertanyaan terhadap 58 responden.Adapun hasil dari jawaban responden dapat dilihat pada tabel berikut : 
Tabel 5

Deskripsi Sarana dan Prasarana

\begin{tabular}{|c|c|c|c|c|}
\hline No & $\begin{array}{l}\text { Kategori } \\
\text { Jawaban }\end{array}$ & $\begin{array}{l}\text { Jumlah Jawaban } \\
\text { Responden }\end{array}$ & $\begin{array}{l}\text { Persentase } \\
(\%)\end{array}$ & $\begin{array}{l}\text { Tingkat } \\
\text { Capaian }\end{array}$ \\
\hline 1 & Ya & 433 & 74,65 & \\
\hline 2 & Tidak & 147 & 25,34 & \\
\hline \multicolumn{2}{|c|}{ Jumlah } & 580 & 100 & $74,65 \%$ \\
\hline
\end{tabular}

Pada Tabel di atas dapat diketahui bahwa dari 58 responden dan dari 10 buahpertanyaan, yang memilih jawaban "Ya" sebanyak 433 responden atau 74,65\%. Dan yang menjawab "Tidak" adalah 147 responden atau 25,34 \%.Secara keseluruhan tingkat capaian sarana dan prasarana terhadap pelaksanaan modifikasi permainan kecil dalam pembelajaran penjasorkes yang ada di Sekolah Dasar Negeri 27 Pangian, berada pada klasifikasi Baik. Gambaran lebih jelasnya deskripsi sarana dan prasarana dapat dilihat pada grafik histogram berikut ini:

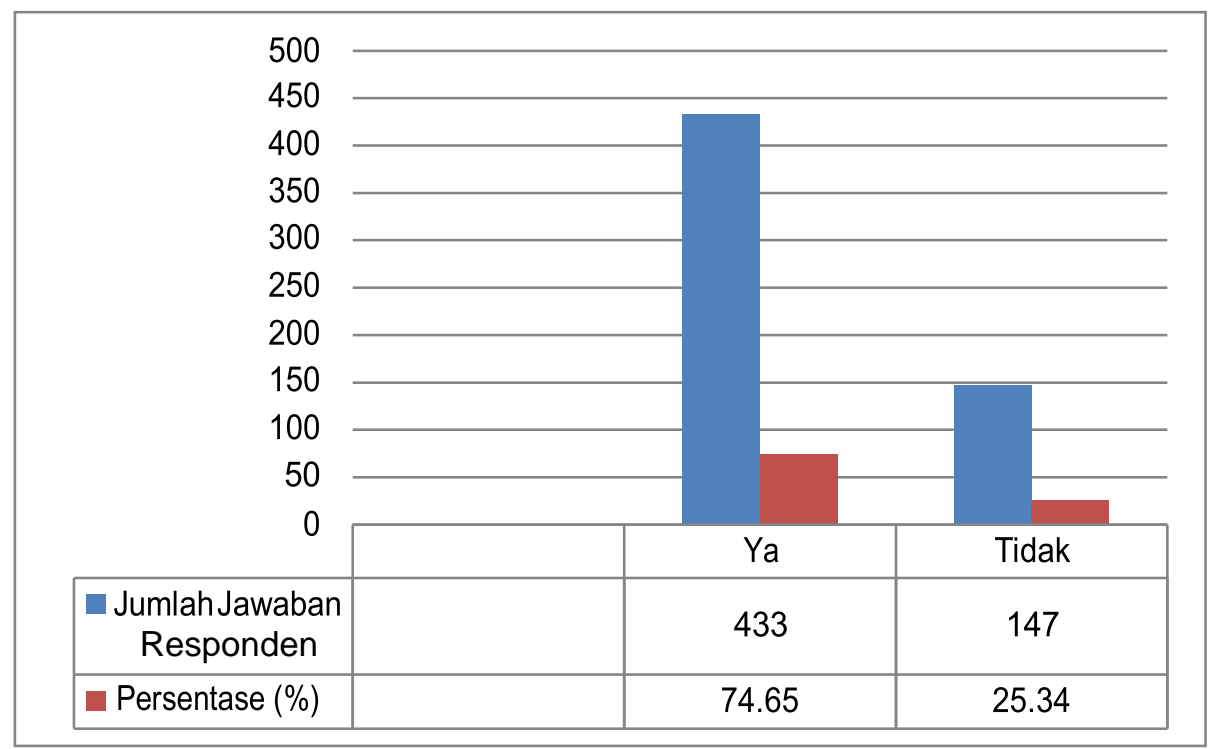

Gambar 3. Histogram Deskripsi Hasil Sarana dan Prasarana

\section{PEMBAHASAN}

Berdasarkan hasil penelitian yang telah diuraikan di atas, variabel motivasi siswa, metode pembelajaran dan sarana dan prasarana merupakan faktor yang mendukung pelaksanaan modifikasi permainan kecil dalam pembelajaran penjasorkes di Sekolah Dasar Negeri 27 Pangian

\section{Motivasi Siswa}

Pada tabel 1 dapat dilihat secara keseluruhan tingkat capaian motivasi siswa yang diperoleh sebesar $85 \%$.Artinya bahwa tingkat capaian motivasi siswa yang ada di Sekolah Dasar Negeri 27 Pangianpada klasifikasi sangat baik.Di sebuah kegiatan pembelajaran dalam dunia pendidikan memang sangat diperlukan 
motivasi bagi siswa, baik motivasi intrinsic maupun motivasi ekstrinsik.Karena Motivasi merupakan Sumber penggerak dan pendorong yang bersifat dinamik, dapat dipengaruhi, merupakan cermin sikap dan pendorong suatu tindakan terarah pada tujuan untuk mendapatkan kepuasan atau menghindari hal-hal yang tidak menyenangkan dengan aspek kognitif, motorik dan efektif. Motivasi harus disesuaikan dengan kebutuhan siswa karena sangat menunjang untuk kelancaran proses belajar mengajar yang efektif dan efisien. Tanpa motivasi yang cukup pendidikan jasmani maka akan sukar untuk mencapai tujuan yang diharapkan. Kesimpulannya adalah motivasi merupakan salah satu aspek penunjang yang sangat penting di dalam pelaksanaan pembelajaran penjasorkes, baik olahraga pendidikan maupun olahraga prestasi.

Berdasarkan hasil tersebut di atas, jelas bahwa tanpa ada motivasi yang cukup baik dari segi kuantitas maupun segi kualitas, hal ini berpengaruh terhadap kelancaran dalam proses belajar mengajar penjasorkes, sehingga dengan kurangnya motivasi, maka pelaksanaan modifikasi permainan kecil dalam pembelajaran penjasorkes tidak akan memuaskan. Jadi salah satu usaha untuk meraih hasil yang baik dalam pendidikan olahraga saat ini akan ditentukan oleh motivasi, baik motivasi intrinsic maupun ekstrinsik. Di Sekolah Dasar Negeri 27 Pangian keadaan motivasi siswa sudah dapat mendukung pelaksanaan modifikasi permainan kecil dalam pembelajaran penjasorkes di tempat tersebut, hanya saja perlu ditingkatkan lagi.

\section{Metode Pengajaran}

Pada Tabel 2 dapat dilihat secara keseluruhan tingkat capaian program latihan yang diperoleh sebesar 85,86\%. Artinya bahwa tingkat capaian metode pengajaran yang ada di Sekolah Dasar Negeri 27 Pangianberada pada klasifikasi sangat baik.

Metode pengajaran adalah hal yang sangat penting dalam sebuah kegiatan pembelajaran, karena itu merupakan sebuah pendorong siswa unuk berbuat dan melakukan intruksi dari guru. Alimunar (2004:3) mengemukakan bahwa " metode adalah jalan menuju tujuan belajar mengajar".Dalam proses belajar mengajar menggunakan metode pengajaran yang berbeda-beda. Metode mengajar adalah suatu cara atau jalan yang harus dilalui didalam mengajar. Hal ini sejalan dengan pendapat Sulih yang dikutip oleh Slameto (1995:65) mengemukakan bahwa "mengajar adalah menyajikan bahan pelajaran oleh seseorang kepada orang lain itu menerima, menguasai dan mengembangkannya".

Metode mempunyai hubungan fungsional yang kaut dengan tujuan memilih dan menetapkan metode berarti telah menetapkan pula tujuan yang akan dicapai. Dalam menyusun strategi, kajian tentang penggunaan metode ini mempunyai kedudukan utama. Ada bermacam-macam metode didalam mengajar seperti : ceramah, diskusi, demonstrasi, dan metode lainnya. Salah dalam memilih metode yang ditetapkan akan mengurangi keberhasilan proses belajar mengajar. Metode mengajar ini harus tepat, agar siswa dapat menerima, menguasai, dan bisa mengembangkan bahan pelajaran yang didapatkan dari guru. Bila metode yang digunakannya kurang baik, hasil belajar siswa juga akan kurang baik.

Berdasarkan hasil tersebut di atas, jelas bahwa tanpa adanya metode yang baik dari guru, maka kemauan dan keseriusan siswa dalam mengikuti pembelajaran akan berkurang. Metode pembelajaran adalah salah satu cara yang 
dapat dilakukan guru untuk menyampaikan meteri yang akan dipelajari sehingga siswa mau dan mampu mencapai tujuan pembelajaran yang diinginkan. Jadi salah satu usaha untuk meraih hasil yang baik dalam pembelajaran penjasorkes saat ini akan ditentukan oleh metode pengajaran yang diberikan oleh guru. Di Sekolah Dasar Negeri 27 Pangian, metode pengajaran yang diberikan oleh guru sudah dapat diklasifikasikan sangat baik, jadi diharapkan dengan metode pengajaran yang seperti itu diharapkan dapat membantu dalam pencapaian tujuan pembelajaran yang lebih baik lagi

\section{Sarana dan Prasarana}

Pada tabel 3 dapat dilihat secara keseluruhan tingkat capaian dukungan tua yang diperoleh sebesar 74,65\%. Artinya bahwa tingkat capaian sarana dan prasarana terhadap pelaksanaan modifikasi permainan kecil dalam pembelajaran penjasorkes yang ada di Sekolah Dasar Negeri 27 Pangianpada klasifikasi Baik.Sarana dan prasarana merupakan salah satu penunjang dalam pelaksanaan pembelajaran. Kelengkapan sarana dan prasarana sangan menentukan dalam sukses atau tidaknya pembelajaran, tanpa sarana dan prasarana pendidikan akan mengalami kendala. Oleh sebab itu sarana dan prasarana merupakan alat vital bagi tercapainya pendidikan.Berdasarkan hasil tersebut di atas, jelas bahwa sarana dan prasarana sangat diperlukan dalam memberi materi pembelajaran gunna mencapai tujuan pembelajaran. Namun di Sekolah Dasar Negeri 27 Pangiansarana dan prasarana belum terpenuhi secara penuh, untuk itulah diharapkan agar lebih dapat memberikan sarana maupun prasarana baik ddari segi kualitas maupun kuantitasnya. Adanya sarana dan prasarana yang mencukupi dan layak pakai diharapkan pelaksanaan pembelajaran penjasorkes dapat berjalan dengan baik sehingga dapat mencapai tujuan pembelajaran yang diharapkan dan pembelajaran bisa terlaksana secara opimal.

\section{SIMPULAN}

1. Tingkat capaian motivasi siswa yang ada di Sekolah Dasar Negeri 27 Pangian berada pada klasifikasi sangat baik, yaitu dengan tingkat capaian jawaban responden mencapai $85 \%$. Artinya bahwa untuk melaksanakan modifikasi permainan kecil dalam pembelajaran penjasorkes, motivasi yang yang ada pada siswa tersebut baik motivasi intrinsic maupun motivasi ekstrinsik di Sekolah Dasar Negeri 27 Pangian sudah sangat baik.

2. Tingkat capaian Metode Pengajaran pada pelaksanaan modifikasi permainan kecil dalam pembelajaran penjasorkes di Sekolah Dasar Negeri 27 Pangian berada pada klasifikasi sangat baik, yaitu dengan tingkat capaian sebesar 85,86

$\%$. Artinya bahwa Metode yang diberikan oleh guru kepada siswa dalam pembelajaran penjasorkes sudah sangat baik.

3. Tingkat capaian sarana dan prasarana terhadap pelaksanaan modifikasi permainan kecil dalam pembelajaran penjasorkes di Sekolah Dasar Negeri 27 Pangian berada pada klasifikasi baik, yaitu dengan tingkat capaian jawaban responden mencapai 74,65 \%. Artinya bahwa sarana dan prasarana dalam pembelajaran penjasorkes yang ada di Sekolah Dasar Negeri 27 Pangianberada dalam klasifikasi Baik. 


\section{DAFTAR PUSTAKA}

Alimunar. (2004). Dasar-Dasar Pendidikan Jasmani. FIK UNP

Arikunto, S. (1998). Manajemen Penelitian. Jakarta : Bina Aksara

Arikunto, S.(1996)..Prosedur Penelitian Suatu Pendekatan Praktek. Jakarta: Bina Aksara

Bucher, C., A (1972) Foundation of Pysycal Education.Third Editn. New York : Mosby Company

Depdikbud. (1993).Dirjen Pendidikan Luar Sekolah Pemuda dan Olahraga.Jakarta: Depdikbud

Gusril.(2004). Beberapa Faktor Yang Berkaitan Dengan Kemampuan Motori Siswa SDN KotaPadang. Desertasi. Jakarta: UNJ

Slameto.(1995).Permainan Kecil. Jakarta. Depdikbud Suwirman.2004 Buku Ajar Penelitian Dasar. Padang : FIK UNP 